\title{
Correction to: Conceptualization of Empowerment and Pathways Through Which Cash Transfers Work to Empower Young Women to Reduce HIV Risk: A Qualitative Study in Tanzania
}

\author{
Joyce Wamoyi ${ }^{1} \cdot$ Peter Balvanz ${ }^{2} \cdot K$ Kaitlyn Atkins ${ }^{2} \cdot$ Margaret Gichane $^{2} \cdot$ Esther Majani $^{3} \cdot$ Audrey Pettifor $^{4,5}$. \\ Suzanne Maman²
}

Published online: 17 December 2020

(c) The Author(s) 2020

\section{Correction to: AIDS and Behavior (2020) 24:3024-3032 10.1007/s10461-020-02850-0}

The article Conceptualization of Empowerment and Pathways Through Which Cash Transfers Work to Empower Young Women to Reduce HIV Risk: A Qualitative Study in Tanzania, written by Joyce Wamoyi · Peter Balvanz - Kaitlyn Atkins · Margaret Gichane · Esther Majani · Audrey Pettifor · Suzanne Maman, was originally published electronically on the publisher's internet portal on 1st April 2020 without open access. With the author(s)' decision to opt for Open
Choice the copyright of the article changed on 12th November 2020 to (C) The Author's 2020 and the article is forthwith distributed under a Creative Commons Attribution.

"The original article has been corrected."

Open Access This article is licensed under a Creative Commons Attribution 4.0 International License, which permits use, sharing, adaptation, distribution and reproduction in any medium or format, as long as you give appropriate credit to the original author(s) and the source, provide a link to the Creative Commons licence, and indicate if changes were made. The images or other third party material in this article are included in the article's Creative Commons licence, unless indicated

The original article can be found online at https://doi.org/10.1007/ s10461-020-02850-0.

Joyce Wamoyi

Jwamoyi@gmail.com

1 National Institute of Medical Research, P.O Box 1462, Mwanza, Tanzania

2 Department of Health Behavior, Gillings School of Global Public Health, University of North Carolina at Chapel Hill, Chapel Hill, NC 27516, USA

3 Sauti ProgramIUSAID Grantee, Dar es Salaam, Tanzania

4 Department of Epidemiology, Gillings School of Global Public Health, University of North Carolina at Chapel Hill, Chapel Hill, NC 27516, USA

5 Carolina Population Center, University of North Carolina at Chapel Hill, Chapel Hill, NC 27516, USA 
otherwise in a credit line to the material. If material is not included in the article's Creative Commons licence and your intended use is not permitted by statutory regulation or exceeds the permitted use, you will need to obtain permission directly from the copyright holder. To view a copy of this licence, visit http://creativecommons.org/licenses/by/4.0/.
Publisher's Note Springer Nature remains neutral with regard to jurisdictional claims in published maps and institutional affiliations. 